\title{
Topic accent and prosodic structure
}

Claudia Crocco - Ghent University (Belgium)

\begin{abstract}
References
This paper aims to contribute to the debate concerning the prominence of the topic by focussing on the general properties of prosodic structure. The perspective I will adopt combines the findings concerning topic accents with general research on prosody.

Topic accents have been studied in several European languages, such as English, German, French, Greek and Italian among others. This paper deals with a regional variety of Italian, Neapolitan Italian, although a number of general considerations could be equally applied to other languages in principle.

In this paper I suggest that the study of topic-related prosodic phenomena should be integrated with the results of the general investigation of prosody, in order to develop an integrated approach. Taking the preceding findings on the prosody of topics and on the phonology of Neapolitan Italian as a starting point, it is argued that topic is not simply associated with a unique accent, rather with a bundle of melodic and rhythmic phenomena.

Furthermore, it is claimed that topical accentual prominences can be seen as part of the general phenomenology of the prosodic structure. In fact, the actual realisation of the prosodic marking is affected by syntagmatic factors: topic accentuation appears to vary according to the different position occupied by the topic with respect to the prosodic nucleus.

Finally, a functional perspective is proposed for the interpretation of the topic-related prosodic events. This perspective is meant to provide a general frame for the analysis of the relationship between the prosodic level and topicality. I propose considering the pragmatic function of topic corresponding, to an abstract prosodic form, which may have several actual realisations according to the actual linear position of the topic in the utterance. By adopting a functional perspective it is possible to take for granted the structural autonomy of prosody and information organisation while analysing the interactions between the two linguistic levels.

The paper is composed of two main parts. The first $(\S \S 2,3)$ presents the theoretical background of this research; the second $(\S \S 4,5)$ analyses and discuss some data from Italian task-oriented speech.

In the first sections a number of studies on topic accent in English and Italian are reviewed $(\S 2)$. The following section $(\S 3)$ sums up several studies providing the theoretical background for the analysis of Neapolitan Italian intonation. Section $\S 4$ is devoted to the analysis of the tonal contour of a number of utterances with and without sentence topics. Finally, in the last sections $(\S \S 4.4,5)$ the results are summarised and discussed and the general conclusions are drawn.
\end{abstract}

\section{References}

Albano Leoni, Federico

2003 Tre progetti per l'italiano parlato. In Italia linguistica anno Mille. Italia linguistica anno Duemila: Atti del XXXIV Congresso Internazionale di Studi della Società di Linguistica Italiana (SLI), Nicoletta Maraschio, and Teresa Poggi Salani (eds.), 675-683, Roma: Bulzoni.

Anderson, Anne H., Miles Bader, Ellen Gurman Bard, Elizabeth H. Boyle, Gwyneth Doherty, Simon C. Garrod, Stephen Isard, Jaqueline Kowtko, Jan McAllister, Jim Miller, Catherine Sotillo, Henry Thompson, and Regina Weinert.

1992 The HCRC Map Task Corpus. Research Paper of the Human Research Communication Centre (HCRC/RP) 29, University of Edinburgh.

Avesani, Cinzia

1995 ToBIt. Un sistema di trascrizione per l'intonazione italiana. Atti delle V giornate di studio del Gruppo di Fonetica Sperimentale (GFS), 1994, Trento, Italy: 85-98.

Avesani, Cinzia, and Mario Vayra

2000 Costruzioni marcate e non marcate in italiano: Il ruolo dell'intonazione. Atti delle X giornate di studio del Gruppo di Fonetica Sperimentale (GFS), 1999, Napoli, Italy: 1-14.

2003 Broad, narrow and contrastive focus in Florentine Italian. Proceedings of the $15^{\text {th }}$ International Congress of Phonetic Sciences (ICPhS), 2003, Barcelona, Spain: 1803-1806. 
2004 Focus ristretto e focus contrastivo in italiano. Il parlato italiano: Atti del Convegno Nazionale, Federico Albano Leoni, Francesco Cutugno, Massimo Pettorino, Renata Savy (eds.), CD-Rom: F01.pdf, Napoli: D'Auria Editore.

2005 Accenting, deaccenting and information structure in Italian dialogues. Proceedings of the $6^{\text {th }}$ International Speech Communication Association Special Interest Group on dialogue (ISCA-SIGdial) Workshop on Discourse and Dialogue, 2005, Lisbon, Portugal: 19-24.

Baumann, Stefan

2006 Information structure and prosody: Linguistic categories for spoken language annotation. In Methods in empirical prosody research, Stefan Sudhoff, Denisa Lenertová, Roland Meyer, Sandra Pappert, Petra Augurzky, Ina Mleinek, Nicole Richter and Johannes Schließer (eds.), 152-179. Berlin/New York: Walter de Gruyter.

Baumann, Stefan, and Martine Grice,

2004 Accenting accessible information. Proceedings of the Second International Conference on Speech Prosody, 2004, Nara, Japan: 21-24.

2006 The intonation of accessibility. Journal of Pragmatics 38 (10): 1636-1657.

Benincà, Paola, Lorenza Frison, and Giampaolo Salvi

2001 L'ordine degli elementi della frase e le costruzioni marcate. In Grande grammatica italiana di consultazione, Lorenzo Renzi, Giampaolo Salvi, and Anna Cardinaletti (eds.), 129-239. Bologna: Il Mulino.

Berruto, Gaetano

1986 Le dislocazioni a destra in italiano. In Tema-Rema in italiano/Theme-Rheme in Italian/ThemaRhema im Italienischen, Harro Stammerjohann (ed.), 55-69. Tübingen: Gunter Narr Verlag.

Bertinetto, Pier Marco (ed.)

2001 AVIP: Archivio delle Varietà dell'Italiano Parlato: CD-Rom. Ufficio Pubblicazioni della Classe di Lettere della Scuola Normale Superiore: Pisa.

Bertinetto, Pier Marco, and Emanuela Magno Caldognetto

1993 Ritmo e intonazione. In Introduzione all'italiano contemporaneo: Le strutture, Alberto A. Sobrero (ed.), 141-192. Bari: Laterza.

Bolinger, Dwight

1965 Forms of English. Cambridge, Massachusetts: Harvard University Press.

Bonvino, Elisabetta

2004 Fenomeni sintattici e prosodici relativi alla distinzione fra due tipi di soggetto postverbale. Il parlato italiano: Atti del Convegno Nazionale, Federico Albano Leoni, Francesco Cutugno, Massimo Pettorino, Renata Savy (eds.), CD-Rom: F02.pdf, Napoli: D’Auria Editore.

Brown, Gillian

1983 Prosodic structure and the Given/New distinction. In Prosody: Models and measurements, Anne

Cutler, D. Robert Ladd, and Gillian Brown (eds.): 67-77. Berlin: Springer-Verlag.

Brown, Gillian, Karen L. Currie, and Joanne Kenworthy 1980 Questions of Intonation. London: Croom Helm.

Büring, Daniel

1997 The Meaning of Topic and Focus: The 59th Street Bridge Accent. London: Routledge.

Canepari, Luciano

1980 Italiano Standard e Pronunce Regionali. Padova: CLUEP.

Caputo, Maria Rosaria

1993 L'intonazione delle domande sì/no in un campione di italiano parlato. Atti delle IV Giornate di

Studio del Gruppo di Fonetica Sperimentale (GFS), 1993, Torino, Italy: 9-18.

1996 Presupposizione, focus, modalità e schemi melodici. Atti del XXIV Convegno Nazionale dell' Associazione Italiana di Acustica (AIA), 1996, Trento, Italy: 49-54.

Carletta, Jean, Amy Isard, Stephven Isard, Jaqueline Kowtko, and Gwyneth Doherty-Sneddon

1996 HCRC dialogue structure coding manual. Technical Report of the Human Communication

Research Centre (HCRC/TR), 82, University of Edinburgh.

Chafe, Wallace

1976 Giveness, contrastiveness, definiteness, subjects, topics and point of view. In Subject and topic, Charles N. Li (ed.), 25-55. New York: Academic Press.

Chilin, Shih

1997 Declination in Mandarin. Proceedings of Intonation: Theory, Models, and Applications. Workshop of the European Speech Communication Association (ESCA), 1997, Athens, Greece: 293-296.

Cresti, Emanuela

2000 Corpus di Italiano Parlato. Firenze: Accademia della Crusca.

Cresti, Emanuela, and Firenzuoli Valentina 
2002 L'articolazione informativa topic-comment e comment-appendice: Correlati intonativi. Atti delle XII giornate di studio del Gruppo di Fonetica Sperimentale (GFS), 2001, Macerata, Italy: 153-166.

Crocco, Claudia, Renata Savy, Francesco Cutugno (eds.)

2003 API: Archivio dell'Italiano Parlato. http://www.parlaritaliano.it/parlare/

Crocco, Claudia, and Renata Savy

2007 Topic in dialogue: prosodic and syntactic features. Proceedings of Interspeech (2007), Antwerp, Belgium,CD-Rom.

Cruttenden, Alan

1993 The de-accenting and re-accenting of repeated lexical items. Proceedings of the European Association of Speech Communication (ESCA) Conference on Prosody, 1993, Lund, Sweden: 16-19.

2006 The de-accenting of given information: a cognitive universal? In Pragmatic organization of discourse in the languages of Europe, Giuliano Bernini, and Marcia L. Schwartz (eds.), 311-356. Berlin/New York: Mouton de Gruyter.

Dealais-Roussarie, Elisabeth, Annie Rialland, Jenny Doetjes, Jean-Marie Marandin

2002 The prosody of post-focus sequences in French. Proceedings of the First International Conference on Speech Prosody, 2002, Aix-en-Provence, France: 239-242.

Di Cristo, Albert, and Ludovic Jankowski

1999 Prosodic organisation and phrasing after focus in French. Proceedings of $14^{\text {th }}$ the International Congress of Phonetic Sciences (ICPhS), 1999, San Francisco, USA: 1565-1568.

D’Imperio, Mariapaola

1999 Tonal structure and pitch targets in Italian focus constituents. Proceedings of the $14^{\text {th }}$ International Congress of Phonetic Sciences (ICPhS), San Francisco, USA: 1757-1760.

2001a Focus and tonal structure in Neapolitan Italian. Speech Communication 33 (4): 339-356.

$2001 \mathrm{~b}$ Tonal alignment, scaling and slope in Italian question and statement tunes. Proceedings of the $7^{\text {th }}$ European Conference on Speech Communication and Technology (Eurospeech), 2001, Aalborg, Denmark: 99101.

2002 Italian intonation: An overview and some questions. Probus 14 (1): 37-69.

2003 Tonal structure and pitch targets in Italian focus constituents. Catalan Journal of Linguistics 2: 55-

65.

D'Imperio, Mariapaola, and Barbara Gili Fivela

2003 How many levels of phrasing? Evidence from two varieties of Italian. In Phonetic interpretation: Papers in laboratory phonology VI, John Local, Richard Ogden, and Rosalind Temple (eds.), 130-144. Cambridge: Cambridge University Press.

Endo, Reiko, and Pier Marco Bertinetto

1997 Aspetti dell'intonazione in alcune varietà di italiano. Atti delle VII Giornate di Studio del Gruppo di Fonetica Sperimentale (GFS), Rome, Italy: 27-49.

Ferrari, Giacomo, Claudia Soria, and Elena Milos

2001 AVIP: Annotazione morfosintattica e testuale-pragmatica. In AVIP: Archivio delle Varietà dell'Italiano Parlato: CD-Rom, Pier Marco Bertinetto (ed.), Pisa: Ufficio Pubblicazioni della Classe di Lettere della Scuola Normale Superiore.

Féry, Caroline

1993 German Intonational Patterns. Tübingen: Niemeyer

Frascarelli, Mara

1997 The phonology of focus and topic in Italian. The Linguistic Review 14: 221-248.

2000 The Syntax-Phonology Interface in Focus and Topic Constructions in Italian.

Dordrecht/Boston/London: Kluwer Academic Publishers.

Frascarelli, Mara, and Roland Hinterhölzl

2007 Types of topics in German and Italian. In On information structure, meaning and form, Suzanne

Winkler, and Kerstin Schwabe (eds.), 87-116. Amsterdam/ Philadelphia: John Benjamins.

Gili Fivela, Barbara

1999 The prosody of left-dislocated topicalized constituents in Italian read speech. Proceedings of the Sixth European Conference on Speech Communication and Technology (Eurospeech) 1999, Budapest, Hungary: 531-534.

2002 Tonal Alignment in two Pisa Italian peak accents. Proceedings of the First International Conference on Speech Prosody, 2002, Aix-en-Provence, France: 339-342.

2003 The phonetics and phonology of intonation: the case of Pisa Italian. Ph.D. diss., Scuola Normale Superiore, Pisa.

Gili Fivela, Barbara, and Michelina Savino

2003 Segments, syllables and tonal alignment: A study on two varieties of Italian. Proceedings of the $15^{\text {th }}$ International Congress of Phonetic Sciences (ICPhS), 2003, Barcelona, Spain: 2933-2936. 
Giordano, Rosa

2006 The intonation of polar questions in two central varieties of Italian. Proceedings of the Third International Conference on Speech Prosody, Dresden, Germany: CD-Rom: PS8-10-155.pdf.

Giordano, Rosa, and Claudia Crocco

2005 Sul rapporto tra intonazione e articolazione informativa. In Italiano parlato: Analisi di un dialogo,

Federico Albano Leoni, and Rosa Giordano (eds.), 159-188, Napoli: Liguori.

Givón, Talmy

1983 Topic continuity in discourse: An introduction. In Topic continuity in discourse: A quantitative cross-language study, Talmy Givón (ed.), 1-41. Amsterdam: John Benjamins.

Grice, Martine

1995 The Intonation of Interrogation in Palermo Italian: Implications for Intonation Theory. Tübingen: Niemeyer.

Grice, Martine and Michelina Savino

1995a Intonation and communicative function in a regional variety of Italian, Phonus, 1: 19-32. Universität des Saarlandes.

1995b Low tone versus 'sag' in Bari Italian intonation: A perceptual experiment. Proceedings of the $13^{\text {th }}$ International Congress of Phonetic Sciences (ICPhS), 1995, Stockholm, Sweden: 658-661.

1997 Can pitch accent type convey information-status in yes-no questions? Proceedings of the Association for Computational Linguistics (ACL 97): Workshop on Concept-to-Speech Generation Systems, Madrid, Spain: 29-38.

Grice, Martine, Michelina Savino, and Mario Refice

1997 The intonation of questions in Bari Italian: Do speakers replicate their spontaneous speech when reading? Phonus, 3: 1-7, Universität des Saarlandes.

Grice, Martine, Mariapaola D’Imperio, Michelina Savino, and Cinzia Avesani

2005 Towards a strategy for labelling varieties of Italian. In Prosodic typology and transcription: A unified approach, Sun-Ah Jun (ed.), 55-83. Oxford: Oxford University Press.

Gundel, Janette

1978 Stress, pronominalisation and the given-new distinction. Working Papers in Linguistics 10 (2): 113, University of Hawaii.

1988 Universals of topic-comment structure. In Studies in syntactic typology, Michael Hammond, Edith. A. Moravscik, Jessica R. Wirth (eds.) 209-239. Amsterdam: John Benjamins.

1998 On different kinds of focus. In Focus: linguistic, cognitive, and computational perspectives, Peter Bosch, and Rob van der Sandt (eds.), 293-305. Cambridge: Cambridge University Press.

Gundel, Jeanette, Nancy Hedberg, and Ron Zacharski

1997 Topic-Comment structure, syntactic structure and prosodic tune. Paper presented at the Workshop on Prosody and Grammar in Interaction, Helsinki, Finland, August 13-15.

Gussenhoven, Carlos

1983 On The Grammar And Semantics Of Sentence Accent. Dordrecht: Foris.

2004 The Phonology of Tone and Intonation. Cambridge: Cambridge University Press.

Hedberg, Nancy

2006 Topic-Focus controversies. In The architecture of focus, Valeria Molnar and Susanne Winkler (eds.), 373-399. Berlin/New York: Mouton de Gruyter.

Hedberg, Nancy, and Juan M. Sosa

2002 The prosody of questions in natural discourse. Proceedings of the First International Conference on Speech Prosody, 2002, Aix-en-Provence, France: 375-378.

2007 The prosody of topic and focus in spontaneous English dialogue. In Topic and focus: Crosslinguistic perspectives on meaning and intonation, Chungmin Lee, Mathew Gordon, and Daniel Büring, (eds.), 101-120. Dordrecht: Springer.

Hirschberg, Julia, and Gregory Ward

1985 Fall-Rise intonation and the place of intonational "meaning" in linguistic theory. Proceedings of the $11^{\text {th }}$ Annual Meeting of the Berkeley Linguistics Society: 447-458.

Interlandi, Grazia

2004 Il continuum della variazione pragmatico-espressiva nell'intonazione dell'italiano parlato a Torino. In Il parlato italiano: Atti del Convegno Nazionale, Federico Albano Leoni, Francesco Cutugno, Massimo Pettorino, Renata Savy (eds.), CD-Rom: F07.pdf, Napoli: D’Auria Editore.

Jackendoff, Ray

1972 Semantic Interpretation in Generative Grammar. Cambridge, Massachussets/London, England: The MIT Press.

Ladd, D. Robert 
1980 The Structure of Intonational Meaning: Evidence from English. Bloomington/London: Indiana University Press.

1996 Intonational Phonology. Cambridge: Cambridge University Press.

Lambrecht, Knud

1994 Information Structure and Sentence Form: Topic, Focus and the Mental Representations of Discourse Referents. Cambridge: Cambridge University Press.

Lambrecht, Knud, and Laura Michaelis,

1998 Sentence accent in information questions: Default and projection. Linguistics and Philosophy 21: 477-544.

Lombardi Vallauri, Edoardo

2001 La teoria come separatrice di fatti di livello diverso. L'esempio della struttura informativa dell'enunciato. In Dati empirici e teorie linguistiche. Atti del XXXIII Congresso della Società di Linguistica Italiana (SLI), Federico Albano Leoni, Eleonora Stenta Krosbakken, Rosanna Sornicola, and Carolina Stromboli (eds.), 151-173. Roma: Bulzoni.

Marotta, Giovanna

2002 L'intonation des énonceés interrogatifs ouverts dans l'Italien Toscan. Proceedings of the First International Conference on Speech Prosody, 2002, Aix-en-Provence, France: 475-478.

Marotta, Giovanna, and Patrizia Sorianello

1999 Question intonation in Sienese Italian. Proceedings of $14^{\text {th }}$ the International Congress of Phonetic Sciences (ICPhS), 1999, San Francisco, USA: 1161-1164.

2001 La teoria autosegmentale nell'analisi dell'intonazione interrogativa di due varietà di italiano toscano (Lucca e Siena). In Dati empirici e teorie linguistiche: Atti del XXXIII Congresso della Società di Linguistica Italiana (SLI), Federico Albano Leoni, Eleonora Stenta Krosbakken, Rosanna Sornicola, and Carolina Stromboli (eds.), 177- 204. Roma: Bulzoni.

Maslova Elena, and Giuliano Bernini

2006 Sentence topics in the languages of Europe and beyond. In Pragmatic organization of discourse in the languages of Europe, Giuliano Bernini, and Marcia L. Schwartz (eds.), 67-120. Berlin/New York: Mouton de Gruyter.

Mereu, Lunella

in press La sintassi dei circostanziali nel parlato. Atti del Convergno internazionale La comunicazione parlata/Spoken communication, Massimo Pettorino, Antonella Giannini, Marianna Vallone, and Renata Savy (eds.).

Mereu, Lunella

2004 La sintassi delle lingue del mondo. Roma/Bari: Editori Laterza.

Mereu, Lunella, and Alessandra Trecci

2004 Focus sul topic. Il Parlato Italiano: Atti del Convegno Nazionale, Federico Albano Leoni, Francesco Cutugno, Massimo Pettorino, and Renata Savy (eds.). Napoli: M. D’Auria Editore (CD-Rom).

Mereu, Lunella, and Mara Frascarelli

2006 L'interfaccia sintassi-fonologia: interpretazione e implicazioni teoriche. In Atti del Secondo convegno nazionale dell'Associazione Italiana di Scienze della Voce (AISV), Renata Savy, and Claudia Crocco (eds.), Torriana: EDK (CD-Rom).

Nakajima, Shin'ya, and James F. Allen

1993 A study on prosody and discourse structure in cooperative dialogues. Phonetica 50: 197-210.

Nespor, Marina

1993 Fonologia. Bologna: Il Mulino.

Pierrehumbert, Janet

1980 The Phonology and Phonetics of English Intonation. Ph.D. thesis, MIT. Distributed by Indiana University Linguistics Club, Bloomington.

Pierrehumbert Janet, and Julia Hirschberg

1990 The meaning of intonational contours in the interpretation of discourse. In Intentions in communication, Jerry Morgan, Philip Cohen and Martha Pollack (eds.), 271-312. Cambridge, Massachusetts: The MIT Press.

Prince, Ellen F.

1981 Toward a taxonomy of given-new information. In Radical pragmatics, Peter Cole (ed.): 223-256. New York: Academic Press.

Savino, Michelina

2001 Non-finality and pre-finality in Bari Italian intonation: A preliminary account. Proceedings of the $7^{\text {th }}$ European Conference on Speech Communication and Technology (Eurospeech), 2001, Aalborg, Denmark: 939-942.

Selkirk, Elisabeth O. 
1984 Phonology and Syntax: The Relation between Sound and Structure. Cambridge, Massachusetts: The MIT press.

Silverman, Kim, Mary Beckman, John F. Pitrelli, Mori Ostendorf, Colin Wightman, Patti Price, Janet Pierrehumbert, and Julia Hirschberg

1992 TOBI: A standard for labeling English prosody. In Proceedings of the Second International

Conference on Spoken Language Processing, (ICSLP), 1992, Banff, Canada: (2) 867- 870.

Sluijter, Agaath, and Jacques Terken

1993 Beyond sentence prosody: Paragraph intonation in Dutch. Phonetica 50: 180-188.

Sornicola, Rosanna

1999 Labile orders and grammatical functions. The functional representation of one argument structures. In Boundaries of morphology and syntax, Lunella Mereu (ed.), pp. 291-305. Amsterdam: John Benjamins.

Steedman, Mark

1991 Structure and intonation. Language 67: 262-296.

Swerts, Marc, Cinzia Avesani, and Emiel Krahmer,

1999 Reaccentuation or deaccentuation: A comparative study of Italian and Dutch. Proceedings of the

$14^{\text {th }}$ International Congress of Phonetic Sciences (ICPhS), Berkeley, USA: 1541-1544.

Swerts, Marc, and Ronald Geluykens

1993 The prosody of information units in spontaneous monologue. Phonetica 50: 189-196.

Swerts, Marc, Eva Strangert, and Mathias Heldner

$1996 \mathrm{~F}_{0}$ declination in spontaneous and read-aloud speech. Proceedings of the $4^{\text {th }}$ International

Conference on Spoken Language Processing (ICSLP), 1996, Philadelphia,USA: 1501-1504.

't Hart, Johan, René Collier, and Antoine Cohen

1990 A Perceptual Study of Intonation: An Experimental-Phonetic Approach. Cambridge: Cambridge

University Press.

Trubetzkoy Nikolai S.

1939 Grundzüge der Phonologie. Prague: Travaux du cercle linguistique de Prague 7.

Umeda Noriko

1982 "F $\mathrm{F}_{0}$ declination" is situation dependent. Journal of Phonetics 10:279-290.

Vallduví, Enric

1992 The Informational Component. New York: Garland Publishing.

Vallduví, Enric, and Elisabet Engdhal

1996 Information packaging in HPSG. Working Papers in Cognitive Science 12, University of Edinburgh.

Vallduví, Enric, and Maria Vilkuna

1998 On rheme and kontrast. In The limits of syntax, Peter Culicover, and Louise McNally (eds.) 79-108.

New-York: Academic Press.

Vallduví, Enric, and Ron Zacharski

1994 Accenting phenomena, association with focus, and the recursiveness of focus-ground. Proceedings

of the Amsterdam Colloquium 9: 683-702.

Yule, George

$\mathrm{Xu}, \mathrm{Yi}$

1980 Speaker's topics and major paratones. Lingua 52: 33-47.

2005 Speech melody as articulatorily implemented communicative functions. Speech Communication 46: $220-251$.

2006a Principles of tone research. Proceedings of International Symposium on Tonal Aspects of Languages, La Rochelle, France: 3-13.

2006b Speech prosody as articulated communicative functions. Proceedings of the Third International

Conference on Speech Prosody 2006, Dresden, Germany.

$\mathrm{Xu}, \mathrm{Yi}, \mathrm{Ching} \mathrm{X}$. Xu and Xuejing Sun

2004 On the temporal domain of focus. Proceedings of the Second International Conference on Speech Prosody, 2004, Nara, Japan: 81-84.

$\mathrm{Xu}, \mathrm{Yi}$, and Ching X. Xu

2005 Phonetic realization of focus in English declarative intonation. Journal of Phonetics 33: 159-197. 